\title{
IMPLEMENTASI PROGRAM KELUARGA SADAR HUKUM DI DESA PATEAN KECAMATAN BATUAN
}

\author{
Yayuk Sugiarti ${ }^{(1)}$ \\ Hidayat Andyanto ${ }^{(2)}$ \\ ${ }^{(1,2)}$ Dosen Fakultas Hukum Universitas Wiraraja \\ yayuksugiarti@wiraraja.ac.id ${ }^{(1)}$ \\ hidayatandyanto@wiraraja.ac.id ${ }^{(2)}$
}

\begin{abstract}
ABSTRAK
Masyarakat desa pada umumnya memiliki tingkat kesadaran hukum yang rendah sehingga mengakibatkan adanya permasalahan hukum. Dengan masih rendahnya tingkat pendidikan mungkin adalah salah satu faktor tidak memahami hukum. Untuk mengatasi kurangnya pemahaman tentang hukum, maka rasanya perlu kiranya diperlukan adanya implementasi Keluarga Sadar Hukum (Kadarkum) secara efektif dan berkesinambungan sehingga masyarakat benar-benar memahami pentingnya hukum di desa Patean Kecamatan Batuan. Penelitian ini bertujuan memahami faktor-faktor yang mempengaruhi kesadaran hukum sehingga nantinya masyarakat dapat mematuhi keberadaan hukum; serta mampu menumbuhkan kesadaran hukum di dalam masyarakat sesuai dengan peraturan yang berlaku yang mengatur kehidupan sosial bermasyarakat. Data yang terdapat dalam penelitian ini, diperoleh dengan melalui tiga cara yaitu observasi, penyuluhan, dan wawancara. Metode analisis data yang digunakan yaitu metode penelitian yuridis normatif yang memadukan aturan hukum yang ada dengan fenomena sosial di dalam masyarakat melalui pengamatan terhadap kegiatan keluarga sadar hukum di desa Patean Kecamatan Batuan.
\end{abstract}

Kata Kunci: Implementasi, Keluarga Sadar Hukum 


\section{JURNAL JENDELA HUKUM}

ISSN Cetak \& Online : 2355-5831/2355-9934

\section{A. PENDAHULUAN}

Hukum dipandang sebagai salah satu aspek yang penting didalam masyarakat dengan tujuan untuk me realisasikan terbentuknya suatu masyarakat yang nyaman dan berkeadilan .kadang kala dengan adanya segelintir orang tidak diindahkan sebagaimana yang dimaksud tersebut diatas.

Hukum tidak jarang juga dicinderai, dilanggar bahkan disalahgunakan fungsi dan manfaatnya oleh seseorang karena demi kepentingannya atau karena menganggap bahwa hukum itu dimata masyarakat kurang penting, sehingga banyak terjadi pelaku pelaku pelanggaran hukum dimasyarakat. Untuk itulah dalam sosiologi hukum disini sebagai orang orang yang kurang sadar tentang hukum.

Hukum disini merupakan peraturan yang terdiri dari perintah, mengikat dan disertai sanksi bagi mereka yang pelanggarnya yang bertujuan untuk mengatur ketentraman dan ketertiban dalam masyarakat khususnya masyarakat patean.. Untuk mencapai ketentraman dan ketertiban dalam masyarakat dibutuhkan sikap masyarakat yang sadar hukum. Tentunya sadar hukum yang dimulai dari penerapan hukum di lingkungan keluarga kita sendiri. Keluarga sadar hukum dibentuk bersdasarkan Surat Edaran Kepala Badan Pembinaan Hukum
Nasional Nomor PHN-05.HN.04.04-20 Tahun 2019 tentang Pedoman Pelaksanaan Verifikasi Pembentukan Desa atau Kelurahan Sadar Hukum, dapat diusulkan oleh Pemerintah Daerah Kabupaten atau Kota Kepada Gubenur melalui Kepala Kantor Wilayah untuk ditetapkan sebagai Desa atau Kelurahan Sadar hukum untuk diberikan Anugerah dari Menteri Hukum dan Hak Asasi Manusia (HAM) yang mana hal ini merupakan strategis dalam rangka mengembangkan kesadaran hukum yang ada di masyarakat baik di Desa atau Kelurahan guna untuk menegakkan supremasi hukum.

Hukum memiliki pengaruh baik secara langsung maupun tidak langsung dalam mendorong munculnya perubahan sosial pada pada lembaga terhadap masyarakat.

Kesadaran hukum merupakan kesadaran akan diri sendiri tanpa tekanan, paksaan, atau perintah dari luar untuk di taati oleh semua lapisan masyarakat. Terkadang hukum yang berlaku seiring berjalannya waktu bahwa kesadaran hukum di masyarakat sebetulnya tidak perlu menjatuhkan sanksi karena masyarakat sudah dianggap tau dan memahami makna akan hukum itu sendiri, dimana Pemerintah dalam memberikan wawasan 


\section{IURNAL JENDELA HUKUM}

ISSN Cetak E Online : 2355-5831/2355-9934

tentang Hukum kepada Masyarakat dengan jalan melalui Sosialisasi dalam bentuk Penyuluhan Hukum, kecuali pada masyarakat yang buta akan hukum dimana masih rendahnya tentang hukum. Masalah hukum yang ada pada masyarakat Desa yaitu masih rendah kesadaran hukumnya , sehingga perlu mendapatkan sanksi karena telah melakukan pelanggaran-pelanggaran.

Hukum sendiri sebenarnya memiliki sifat-sifat universal dan statis terhadap masyarakat yang artinya bahwa hukum berlaku bagi semua lapisan masyarakat, baik pada masyarakat desa maupun pada masyarakat kota, baik laki maupun perempuan serta baik orang dewasa maupun terhadap anak-anak.

Sedang Hukum yang ada di Indonesia sendiri dinamakan Hukum Positif, yang artinya bahwa Hukum yang berlaku di Indonesia pada saat ini, Dimana Hukum ada dua jenis yaitu Hukum Perdata dan Hukum Pidana, Kalu Hukum Perdata mengatur tentang perorangan atau tentang person yang diatur dalam Kitab Undangundang Hukum Perdata (KUHPerdata) sedang Hukum Pidana mengatur tentang kepentingan Umum yang ada di Masyarakat yang diatur dalam kitab Undang-Undang Hukum Pidana (KUHP) dimana dua duanya sama sama sudah dikodifikasikan atau dibukukan. Selain hukum yang tertulis juga ada hukum yang tidak tertulis yaitu yang tidak dibukukan seperti hukum adat.

Di Desa pada umumnya memiliki tingkat kesadaran hukum yang kurang selama didesa tersebut belum pernah tersentuh dengan adanya Pembinaaan Hukum dengan cara sosialisasi yang dikemas dalam bentuk penyuluhan. Dengan rendahnya hukum sehingga mengakibatkan timbulnya permasalahan hukum dimana masyarakat yang ada Desa belum merima dan memahaminya akan adanya aturan yang sebenarnya ini didalam masyarakat Desa atau Kelurahan yang telah dibukukkan. Sehingga masyarakat diharapkan untuk diberi bimbingan yang mungkin adalah salah satu faktor sehingga tidak memahami hukum. Untuk mengatasi kurangnya pemahaman tentang hukum, maka perlu kiranya diperlukan adanya implementasi Keluarga Sadar Hukum (Kadarkum) secara efektif dan berkesinambungan sehingga masyarakat benar-benar memahami pentingnya hukum di desa Patean Kecamatan Batuan.

Implementasi ini pada prinsipnya adalah bentuk komunikasi dengan masyarakat melalui pengamatan yang memadukan aturan hukum yang ada dengan fenomena sosial yang terjadi di masyarakat. Inti dari adanya implementasi kadarkum ini adalah perlunya penyebaran informasi dan 


\section{IURNAL JENDELA HUKUM}

ISSN Cetak E Online : 2355-5831/2355-9934

pemahaman terhadap norma hukum dan peraturan yang berlaku. Baik secara tertulis maupun secara tidak tertulis, sehingga nantinya masyarakat dapat mewujudkan dan mengembangkan kesadaran hukum dalam bentuk tertib dan taat pada norma hukum yang berlaku.

\section{B. PEMBAHASAN}

\section{Kesadaran Hukum Masyarakat}

Untuk mengetahui tentang kesadaran hukum yang ada dimasyarakat ada beberapa beberapa variabel yang kami teliti yaitu:

\section{a. Pengetahuan Masyarakat Perihal Hukum}

Hukum menjadi salah satu komponen yang sangat penting dalam kehidupan masyarakat, oleh karena itu menjadi hal sangat penting untuk mensosialisasikan hukum kepada segenap lapisan masyarakat. Hal ini bertujuan agar kehidupan masyarakat terjalin secara tentram dan damai. Sesuai dengan tujuan hukum, bahwa salah satu tujuan hukum adalah untuk membentuk masyarakat yang damai, taat hukum dan sejahtera. Hukum juga menjadi alat yang tepat sebagai penegak keadilan dalam masyarakat, sehingga sebagaimana teori tujuan hukum, yaitu keadilan, kepastian dan kemanfaatan akan bisa diwujudkan.

Kuantitas masyarakat yang sangat banyak, masalah tersendiri untuk mewujudkan masyarakat

berpengatahuan perihal hukum. Satu persatu masyarakat tidak mungkin untuk memiliki wawasan dan pengetahuan yang optimal perihal hukum, maka kemudian kesadaran masyarakat akan hukum tidak akan terwujud diakibatkan masyarakat yang belum memiliki pemahaman perihal hukum.

Masyarakat sadar akan adanya hukum yang mengatur tingkah laku manusia untuk mencapai tujuan dari Negara Indonesia yang tercantum dalam pancasila untuk merealisasikan tujuan tersebut maka kita wajib menaati peraturan-peraturan atau hukum yang berlaku di Indonesia. Masyarakat sadar dan mengakui akan keberadaan hukum namun terkadang acuh dan tidak peduli akan adanya hukum.

Pentingnya pendidikan juga berperan penting dalam menyadarkan masyarakat akan pentingnya sadar hukum bahwasanya hukum yang dibuat adalah tujuan baik untuk mengatur hubunganmasyarakat, melindungi hak dan kewajiban sebagai warga Negara. Dimana dalam penerapannya perlu adanya pemaksaan dan sanksi sehingga hukum tersebut berjalan sesuai dengan tujuan bangsa Indonesia.

\section{b. Sikap Masyarakat Terhadap Hukum}

\section{Menurut}

kesadaran hukum adalah seluruh kompleks kesediaan warga masyarakat 


\section{IURNAL JENDELA HUKUM}

ISSN Cetak E Online : 2355-5831/2355-9934

untuk berperilaku sesuai dengan keharusan yang ditetapkan oleh hukum. Kesadaran hukum akan memotivasi masyarakat untuk secara sukarela menyesuaikan segala perilakunya kepada ketentuan hukum perundang-undangan negara yang berlaku. Menurut Soerjono Soekanto kesadaran hukum adalah persoalan nilai-nilai yang terdapat pada diri manusia tentang hukum yang ada. Sebenarnya yang ditekankan adalah nilainilai tentang fungsi hukum dan bukan suatu penilaian hukum terhadap kejadiankejadian yang konkrit dalam masyarakat yang bersangkutan. Jadi kesadaran hukum dalam hal ini berarti sadar untuk bertindak sesuai dengan ketentuan hukum.

Berdasarkan definisi di atas dapat ditarik kesimpulan bahwa kesadaran hukum merupakan cara pandang masyarakat terhadap hukum, apa yang seharusnya dilakukan dan tidak dilakukan terhadap hukum yang dipengaruhi oleh akal, agama, politik, ekonomi dan lain sebagainya. Bisa juga dikatakan bahwa kesadaran hukum merupakan kesadaran dari diri seseorang yang tanpa tekanan, perintah, atau pun paksaan dari luar agar tunduk serta patuh terhadap hukum.

Kesadaran hukum berasal dari perspektif atau cara pandang masyarakat masing-masing bahwa hukum yang dibuat berasal dari masyarakat dan untuk masyarakat sendiri perlu adanya paksaan dalam mengimplementasikannya setiap hak dan kewajiban yang terdapat dalam diri manusia sejak lahir yang tidak dapat dikekang atau dibatasi namun ada kalanya hukum dapat membatasinya karena dalam hak kita juga terdapat hak orang lain untuk diperhatikan. Manusia merupakan makhluk sosial sehingga perlu ada aturan yang membatasi tingkah lakunya demi kepentingan bersama.

Hukum sendiri dibagi menjadi dua yaitu hukum tertulis dan hukum yang tidak tertulis dimana masyarakat menaati peraturan yang tertulis seperti KUHP dan BW dimana didalamnya sudah terdapat sanksi yang mengatur sesuai dengan ventuk pelanggarannya sehingga masyarakat menaati karena adanya sanksi bukan karena sadarnya atau pentingnya hukum dalam kehidupan bermasyarakat.

2. Faktor yang Mempengaruhi Kesadaran Hukum

Beberapa faktor yang mempengaruhi kesadaran hukum menurut Soerjono Soekanto yaitu:

a. Pengetahuan tentang ketentuan hukum.

Peraturan yang telah disahkan kadangkala akan tersebar luas dan diketahui oleh masyarakat. Akan tetapi pada prosesnya, terkadang ada masyarakat yang tidak mengetahui hal tersebut karena kurangnya sosialisasi; 


\section{IURNAL JENDELA HUKUM}

ISSN Cetak E Online : 2355-5831/2355-9934

merupakan tugas pemerintah untuk memberikan edukasi terhadap masyarakat yang awam atai tidak tahu akan hukum yang berlaku di Indonesia. Jika terjadi sesuatu perbuatan yang melanggar hukum tidak ada alasan untuk tidak mengetahui akan hukum tersebut.

b. Pengakuan terhadap ketentuan hukum. Masyarakat mengakui keberadaan tentang hukum, tetapi masih banyak warga yang belum mematuhi dan memahami suatu ketentuan hukum tersebut; Keberadaan hukum memang diketahui masyarakat namun apakah masyarakat mengimplementasikaanya sesuai dengan peraturannya karena masyarakat takut akan penegak hukum bukan terhadap hukum yang berlaku padahal hukum diciptakan untuk kepentingan masyarakat serta keamanan dan menjaga hak dan kewaiban dalam berwarga Negara.

c. Penghargaan terhadap ketentuan hukum Penghargaan terhadap hukum merupakan tolak ukur sejauh mana suatu peraturan yang dilarang hukum dapat diterima dengan baik oleh masyarakat. Masyarakat ada yang mematuhi terkadang juga menentang kebijakan hukum; Lingkungan sekitar dapat mempengaruhi kondisi seseorang yang sadar akan adanya hukum namun tetap melanggar sehingga lingkungan yang baik akan mempengaruhi tingkah laku seseorang dalam menaati peraturan yang berlaku sehingga tidak melanggar hukum bahkan mendapat sanksi dalam penegakannya.

d. Pentaatan terhadap ketentuan hukum Semua kepentingan yang ada di masyarakat harus berdasarkan nilainilai hukum yang berlaku. Masyarakat harus dapat memilah mana yang dilarang maupun tidak. Terkadang masyarakat patuh terhadap hukum karena ada rasa takut pada sanksi bukan karena kesadaran dalam dirinya Memang benar dalam pemikiran masyarakat seseorang tunduk akan adanya hukum bukan karena menaati hukum tersebut namun karena ada seseorang yang bertugas dalam penegakan hukum itu sendiri bukan takut terhadap hukum namun kepada penegaknya. Dapat dipastikan jika tidak menanam rasa sadar akan hukum maka dapat dipastikan seseorang dapat melanggar hukum jika ada kesempatan untuk melanggar seperti jika tidak ada aparat penegak hukum itu sendiri. Maka hal tersebut bukan dikatakan sadar akan adanya hukum namun ketakutan masyarakat terhadap penegak hukum bukan takut terhadap peraturan dan dampak yang akan 


\section{IURNAL JENDELA HUKUM}

ISSN Cetak E Online : 2355-5831/2355-9934

ditimbulkan terhadap dirinya dan orang disekitarnya.

\section{Tingkat Kesadaran Hukum}

\section{Masyarakat}

Tingkat Kesadaran Hukum.

Menurut Soekanto dalam Nurhidayat, indikator-indikator dari kesadaran hukum sebenarnya merupakan petunjuk yang relatif kongkrit tentang taraf kesadaran hukum. Dijelaskan lagi secara singkat bahwa :

- Indikator pertama adalah pengetahuan hukum Seseorang mengetahui bahwa perilaku-perilaku tertentu itu telah diatur oleh hukum. Peraturan hukum yang dimaksud disini adalah hukum tertulis maupun hukum yang tidak tertulis. Perilaku tersebut menyangkut perilaku yang dilarang oleh hukum maupun perilaku yang diperbolehkan oleh hukum.

- Indikator kedua adalah pemahaman hukum Seseorang pelajar mempunyai pengetahuan dan pemahaman mengenai aturan-aturan tertentu, misalnya adanya pengetahuan dan pemahaman yang benar dari pelajar tentang hakikat dan arti pentingnya peraturan disekolah.

- Indikator yang ketiga adalah sikap hukum Seseorang mempunyai kecenderungan untuk mengadakan penilaian tertentu terhadap hukum.

- Indikator yang keempat adalah perilaku hukum, yaitu dimana seseorang atau pelajar mematuhi peraturan yang berlaku.

Keempat indikator tadi sekaligus menunjukkan pada tingkatan kesadaran hukum tertentu di dalam perwujudannya. Apabila seseorang hanya mengetahui hukum, maka dapat dikatakan bahwa tingkat kesadaran hukumnya masih rendah, tetapi kalau seseorang dalam suatu masyarakat telah berperilaku sesuai dengan hukum, maka kesadaran hukumnya tinggi.

\section{Proses meningkatkan Kesadaran hukum masyarakat}

Peningkatan kesadaran hukum masyarakat pada dasarnya dapat dilakukan melalui dua cara yaitu dalam bentuk tindakan (action) dan pendidikan (education). Berikut penjelasannya:

1. Tindakan (action)

Tindakan penyadaran hukum pada masyarakat dapat dilakukan berupa tindakan drastic, yaitu dengan memperberat ancaman hukum atau dengan lebih mengetatkan pengawasan ketaatan warga Negara terhadap Undang-Undang. Cara ini bersifat isidentil dan kejutan yang merupakan tindakan tepat untuk meningkatkan kesadaran masyarakat

2. Pendidikan (education)

Pendidikan dapat dilakukan baik secara formal maupun nonformal. Menanamkan kesadara hukum berarti 


\section{IURNAL JENDELA HUKUM}

ISSN Cetak E Online : 2355-5831/2355-9934

menanamkan nilai-nilai kebudayaan dapat dicapai dengan pendidikan. Oleh karena itu setelah mengetahui kemungkinan sebab-sebab merosotnya kesadaran hukum masyarakat usaha pembinaan yang efektif dan efisien ialah dengan pendidikan.

a. Pendidikan formal

Pendidikan sekolah merupakan hal yang lumrah dalam kehidupan berbangsa dan bernegara. Pendidikan kesadaran hukum di sekolah harus dilakukan dari tingkat rendah sampai jenjang pendidikan tinggi (PT);

b. Pendidikan non formal

Pendidikan non formal ditujukan kepada masyarakat luas meliputi segala lapisan dalam masyarakat. Pendidikan non formal dapat dilakukan dengan beberapa cara, antara lain: penyuluhan hukum, kampanye, dan pameran. Penyuluhan hukum adakah kegiatan untuk meningkatkan kesadaran hukum masyarakat berupa penyampaian dan penjelasan peraturan hukum kepada masyarakat dalam suasana informal agar setiap masyarakat mengetahui dan memahami apa yang menjadi hak, kewajiban dan wewenangnya, sehingga tercipta sikap dan prilaku berdasarkan hukum, yakni disamping mengetahui, memahami, menghayati sekaligus mematuhi atau mentaatinya.

\section{KESIMPULAN}

Hukum menjadi salah satu komponen yang sangat penting dalam kehidupan masyarakat, oleh karena itu menjadi hal sangat penting untuk mensosialisasikan hukum kepada segenap lapisan masyarakat terutama masyarakat yang hidup di pedesaan yang belum mengetahui betul akan fungsi dan tujuan hukum itu sendiri. Maka, masyarakat merupakan peran paling utama dalam merealisasikan tujuan dari hukum itu sendiri. Salah satu yang mempengaruhi yaitu tingkat pendidikan yang ada di masyarakat terlebih masyarakat pedesaan agar memahami pentingnya hukum dalam kehidupan bermasyarakat untuk mengurangi pelanggaran hukum.

Kurangnya kesadaran masyarakat terhadap hukum yang dipengaruhi dari beberapa faktor diantaranya pengetahuan, pengakuan, penghargaan dan pentaatan tentang hukum menjadi hal mendasar dalam merealisasikan tujuan dari hukum sendiri. Terdapat beberapa tindakan yang harus dilakukan masyarakat terutama masyarakat pedesaan dalam merealisasikannya. Memperberat ancaman hukum atau dengan lebih mengetatkan pengawasan ketaatan warga Negara terhadap UndangUndang salah satu cara dalam 


\section{IURNAL JENDELA HUKUM}

ISSN Cetak E Online : 2355-5831/2355-9934

meningkatkan kesadaran hukum

dilingkungan masyarakat.

\section{DAFTAR BACAAN}

\section{Buku}

Soekanto, Soerjono, "Penegakan Hukum dan Kesadaran Hukum", Naskah Lengkap pada paper pada seminar Hukum Nasional ke IV, Jakarta, th

Soekanto, Soerjono. Faktor-faktor yang Mempengaruhi Penegakan Hukum, Jakarta, Raja Grafindo Persada, 2004

Soetandyo Wignjosoebroto., Hukum, Paradigma, Metode dan Dinamika Masalahnya., Jakarta: Elsan \& Huma.

Sunaryati Hartono, Peranan Kesadaran Hukum Rakyat dalam Pembaharuan Hukum, Kertas Kerja pada Simposium Kesadaran Hukum Masyarakat dalam Masa Transisi, Jakarta : BPHN-Bina Cipta, 1975

Wignjosoebroto, Soetando, Hukum Dalam Masyarakat, Perkembangan Dan Masalahna, Sebuah Pengantar Ke Arah Kajian Sosiologi Hukum, Malang: Banyumedia Publising, Cet. 2008

\section{Undang-Undang}

Kitab Undang undang Hukum Pidana Kitab Undang undang Hukum Perdata 